\title{
PIOTR GUZOWSKI
}

Instytut Historii i Nauk Politycznych Uniwersytetu w Białymstoku

RADOSŁAW PONIAT

Instytut Historii i Nauk Politycznych Uniwersytetu w Białymstoku

\section{MIEJSCE BADAŃ KWANTYTATYWNYCH WE WSPÓŁCZESNEJ HISTORIOGRAFII POLSKIEJ}

Od pewnego czasu historycy gospodarczy, a zwłaszcza demografowie historyczni, obserwują z niepokojem rozchodzenie się dróg badaczy wykorzystujacych w swoich analizach źródeł metody statystyczne oraz naukowców stosujących inne, klasyczne i nowoczesne narzędzia warsztatu historyka ${ }^{1}$. Mimo iż od kilkudziesięciu lat kwantytatywne podejście do źródeł masowych jest standardem w historiografii zachodnioeuropejskiej i amerykańskiej, artykuły prezentujące wyniki tego typu badań przestały się ukazywać w czasopismach historycznych o charakterze ogólnym i zaczęły trafiać do periodyków specjalistycznych, które, choć prezentuja znakomity poziom naukowy, pozostaja na marginesie głównych nurtów historiografii. W konsekwencji większość zawodowych historyków nie tylko nie zna owoców pracy badaczy z zakresu historii gospodarczej i demografii historycznej, ale również charakterystycznych dla tych specjalności metod, przeżywających wraz z rewolucją informatyczna prawdziwy rozkwit.

Znakomite wykorzystywanie metod statystycznych czy wręcz ekonometryczne podejście do analizy informacji źródłowych zestawionych $\mathrm{w}$ postaci często niezwykle rozbudowanych baz danych sprawiły, że większego zrozumienia historycy „liczący” mogą oczekiwać ze strony ekonomistów niż kolegów z branży, unikających metod kwantytatywnych. Ta metodologiczna separacja skłoniła władze Międzynarodowej

${ }^{1}$ R.W. Fogel, The Limits of Quantitative Methods in History, „The American Historical Review" 80, 1975, s. 329-350; J.F. Reynolds, Do Historians Count Anymore? The Status of Quantitative Methods in History, 1975-1995, „Historical Methods” 31, 1998, s. $141-148$. 
Komisji Demografii Historycznej do przygotowania specjalnego panelu pt. „What General Historians Can Learn from Historical Demography?" (26 VIII 2010 r.) podczas ostatniego, 21. Międzynarodowego Kongresu Nauk Historycznych w Amsterdamie, na którym to panelu przypomniano główne zalety stosowania metod statystycznych nie tylko w spojrzeniu na demografię dawnych społeczeństw, ale także na ich gospodarkę. Problemem tego spotkania był jednak fakt, że doskonałych wystapień Bruce'a Fettera, Andersa Brändströma, Renzo Derosas, Alison Mackinnon i Roberta McCaa wysłuchali tylko historycy praktykujący kwantytatywne podejście do źródeł na co dzień. Ta dosyć przygnębiająca konstatacja związana $\mathrm{z}$ nauka zachodnią stała się inspiracją do zwrócenia naszej uwagi na miejsce metod kwantytatywnych w polskiej historiografii ${ }^{2}$.

Wydaje się, że sytuacja nie powinna być zła. Od ponad pół wieku dysponujemy znakomitym i wciąż w pewnej mierze aktualnym opracowaniem wprowadzajacym Witolda Kuli pt. Problemy $i$ metody historii gospodarczej $j^{3}$, doczekaliśmy się także trzech podręcznikowych ujęć statystyki w badaniach historycznych ${ }^{4}$ oraz znakomitych wykładów metodologii badań demograficznych Ireny Gieysztorowej i Cezarego Kukli ${ }^{5}$. W dodatku statystyka była przez wiele lat przedmiotem obowiazkowym na studiach historycznych, narzuconym przez minima programowe, choć należy zauważyć, że historia gospodarcza w ostatnim okresie nie była wymagana przez decydentów ministerialnych, a demografia historyczna cyklicznie była wprowadzana do grupy przedmiotów obowiązkowych lub wyrzucana z niej. Tym niejednoznacznym - bo trudno powiedzieć, że wyjątkowo niekorzystnym - uwarunkowaniom instytucjonalno-dydaktycznym towarzyszył jednak zauważalny spadek zainteresowania historia gospodarczą i demografią historyczna, a co za tym idzie zmarginalizowanie metod statystycznych w praktykowanych badaniach historycznych. Celem tego artykułu jest zwrócenie uwagi na miejsce metod kwantytatywnych we współczesnych polskich badaniach historycznych.

\footnotetext{
${ }^{2}$ Pierwotna wersja tego tekstu została zaprezentowana podczas dyskusji na temat perspektyw rozwoju nauk historycznych, zorganizowanej z okazji obchodów jubileuszu 80-lecia Instytutu Historii UW, 21 X 2010.

${ }^{3}$ W. Kula, Problemy i metody historii gospodarczej, Warszawa 1963.

${ }^{4}$ M. Dyba, A. Obersztyn, Elementy statystyki dla historyków, Katowice 1978; A. Burzyński, Elementy statystyki dla historyków, Kraków 1980; M. Kopczyński, Podstawy statystyki. Podręcznik dla humanistów, Warszawa 2005.

${ }^{5}$ I. Gieysztorowa, Wstep do demografii staropolskiej, Warszawa 1976; C. Kuklo, Demografia Rzeczypospolitej przedrozbiorowej, Warszawa 2009.
} 
Aby zminimalizować znaczenie subiektywnych obserwacji i wrażeń autorów tego tekstu, wyniesionych z dyskusji podczas szeregu konferencji naukowych organizowanych $\mathrm{w}$ ostatnich latach, których tematyka związana $\mathrm{z}$ analizą źródeł masowych nie sprowokowała jednak referentów do wykorzystania metod kwantytatywnych, zdecydowano uciec się do statystycznego ujęcia zagadnienia. Postanowiono zanalizować pod kątem zastosowania metod kwantytatywnych artykuły opublikowane $\mathrm{w}$ ciagu ostatnich pięćdziesięciu lat na łamach czterech ważnych czasopism historycznych: dwóch wydawanych przez różne środowiska naukowe prestiżowych periodyków ogólnohistorycznych, a więc warszawskiego „Przeglądu Historycznego” i poznańskich „Roczników Historycznych”, oraz dwóch pism „branżowych”, publikujących teksty z zakresu historii gospodarczej i demografii historycznej, czyli „Roczników Dziejów Społecznych i Gospodarczych” oraz „Przeszłości Demograficznej Polski”. Pod uwagę zostały wzięte tylko artykuły i artykuły polemiczne (dyskusje), pominięto zaś recenzje, sprawozdania i omówienia materiałów źródłowych. Wyniki analizy zestawionego $\mathrm{w}$ postaci skromnej bazy danych materiału przedstawiono $\mathrm{w}$ formie czterech wykresów.

Zaprezentowane na wykresie 1 dane opisuja częstotliwość, z jaka $\mathrm{w}$ artykułach zawartych w omawianych czasopismach pojawiają się tabele

Wykres 1. Procent artykułów zawierajacych tabele lub wykresy w wybranych czasopismach historycznych w latach 1951-2010

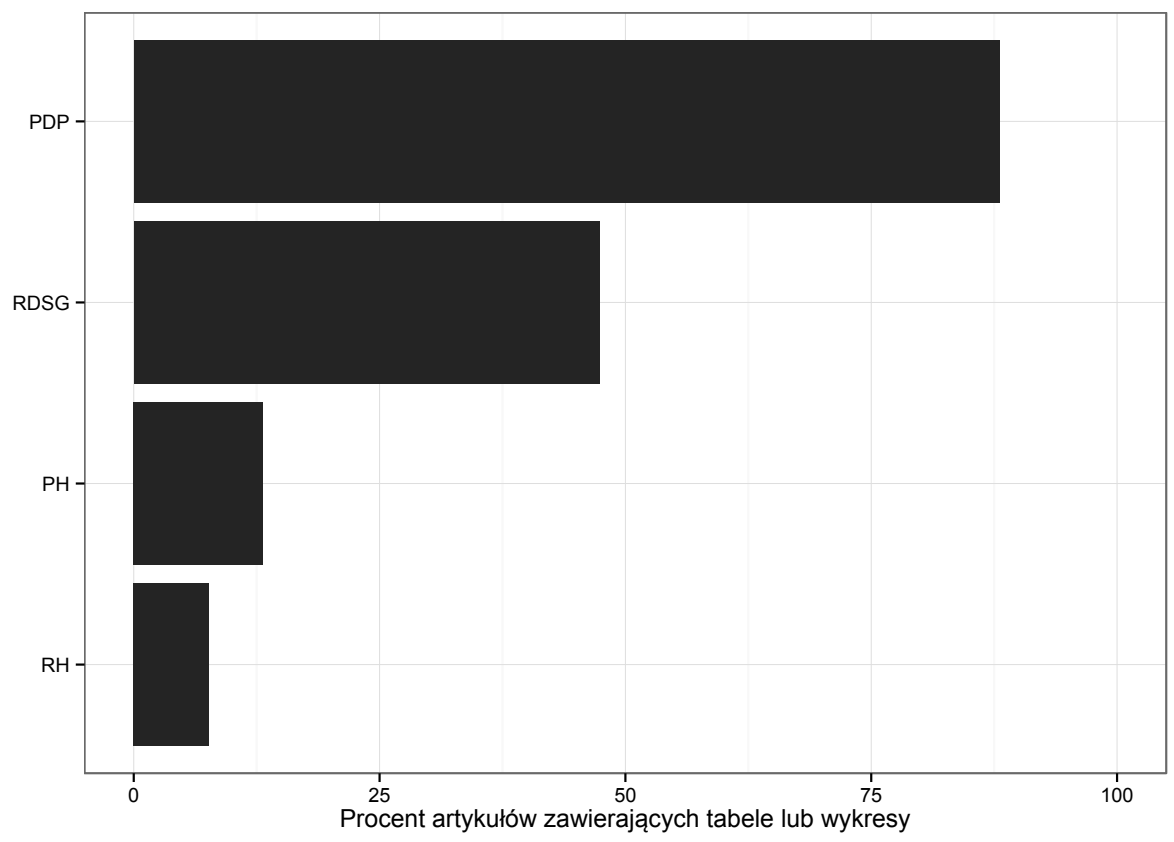


oraz wykresy. Uznać to należy za wskaźnik wykorzystania metod statystycznych, choć autorzy tych słów zdają sobie sprawę z jego ograniczeń, skoro w części artykułów tabele nie stają się podstawą do nawet najprostszej analizy kwantytatywnej. Sporadycznie można też napotkać publikacje sięgające po metody statystyczne, ale bez tabel i wykresów. Zaprezentowane dane wskazują na wyraźna przewagę PDP, gdzie ponad $80 \%$ artykułów zawiera choć jedną tabelę lub wykres. Na drugim miejscu znalazły się RDSG, w których w prawie połowie tekstów sięgnięto po takie formy prezentacji danych. Artykuły publikowane w czasopismach o bardziej ogólnohistorycznym charakterze znacznie rzadziej zawieraja analizy dokonywane metodami statystycznymi, co szczególnie wyraźnie widać w przypadku $\mathrm{RH}$. W nich prawie $95 \%$ tekstów obchodzi się bez tabel i wykresów.

Przedstawione powyżej dysproporcje w stosowaniu metod statystycznych w sposób bardziej szczegółowy pokazane zostały na wykresie 2 . Wykorzystana w nim metoda prezentacji wyników za pomocą wykresów skrzynkowych, choć sporadycznie spotykana w pracach polskich historyków, stanowi jeden z najpopularniejszych we współczesnej statystyce sposobów graficznego przedstawiania danych. Widoczne tu skrzynki $^{6}$ (zwane też „pudełkami”) wskazują zakres między pierwszym a trzecim kwartylem obserwacji i tym samym obejmuja środkowe 50\% analizowanych artykułów. Wychodzące poza ten zakres linie (nazywane „wassami”) wskazuja, gdzie powinny się znajdować prawie wszystkie artykuły z wyłączeniem jedynie wyraźnie różniących się od większości tzw. obserwacji odstających. Znajdująca się w środku skrzynek pogrubiona linia określa położenie mediany.

Jak wyraźnie wynika z prezentowanego tu wykresu, tylko w przypadku tabel występujących w artykułach opublikowanych w PDP wartość ta różni się od zera. Oznacza to, że we wszystkich pozostałych przypadkach ponad połowa publikacji nie zawiera ani jednaj mapy, tabeli lub wykresu. Co więcej, obserwowane tu często sytuacje, gdy na wykresie zamiast skrzynki widoczna jest tylko pojedyncza linia, wskazują na jeszcze wyraźniejszą dominację tekstów pozbawionych graficznej prezentacji danych. Brak skrzynki oznacza, że bez takich metod obchodzi się co najmniej 75\% publikacji. Jeśli na wykresie obok pogubionej linii pojawiaja się tylko punkty wskazujące na istnienie obserwacji odstających, uznać to należy za dowód, że w danym czasopiśmie

${ }^{6}$ Wykres skrzynkowy upowszechnił się statystyce dzięki fundamentalnej, a w Polsce w niestety wciąż słabo znanej pracy Johna W. Tukeya, Exploratory Data Analysis, Reading 1977. 
Wykres 2. Występowanie tabel, wykresów i map w artykułach zamieszczonych w wybranych czasopismach historycznych w latach 1951-2010

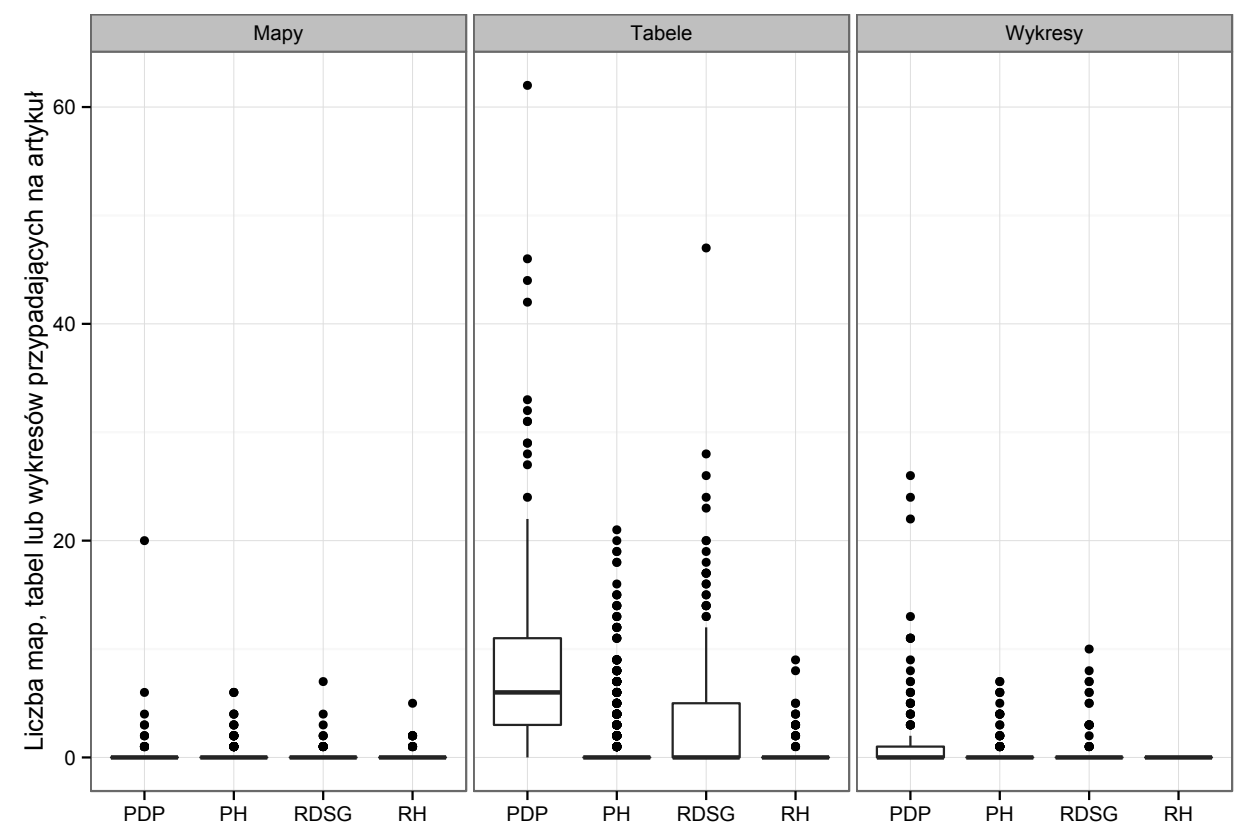

określona forma prezentacji danych stanowi raczej odstępstwo od reguły. Zjawisko to szczególnie wyraźnie widać na przykładzie map, które we wszystkich czasopismach pojawiaja się rzadko ${ }^{7}$, i dotyczy to nawet publikacji dotyczacych kwestii takich jak zmiany granic czy przebieg szlaków handlowych! Mianem wysokich trudno też określić wyniki dotyczące występowania wykresów. Nawet w PDP większość artykułów obchodzi się bez nich, a w pozostałych czasopismach ich sporadyczne pojawianie się uznać należy za sytuacje wyjątkowe. Jedynie tabele pojawiają się w omawianych czasopismach częściej ${ }^{8}$ W PDP

\footnotetext{
${ }^{7}$ Sporadyczność ich występowania oraz fakt, że w wielu przypadkach były to reprodukcje z wcześniejszych prac, spowodowały wyłączenie map z innych prowadzonych tu analiz.

${ }^{8} \mathrm{~W}$ świetle teoretycznych ujęć dotyczacych metod prezentacji danych, wyraźna przewaga tabel nad wykresami wskazuje pośrednio na jeszcze jedną cechę polskich prac historycznych - znacznie częściej służyć one mają prezentacji uzyskanych wyników niż obronie postawionych przez autorów hipotez. Pierwsze z tych zadań lepiej spełniaja tabele, które pozwalaja na stosunkowo łatwe wykorzystywanie zawartych w nich danych w pracach innych historyków. Wykresy z kolei stanowią skuteczniejsze narzędzie służące do przekonywania czytelników. Podstawową pracą omawiającą rolę grafiki w prezentacji danych jest książka Edwarda R. Tufte, The Visual Display of Quantitative Information, Cheshire 1983.
} 
połowa artykułów ma ich 5 lub więcej, w RDSG zaś około połowy tekstów ma choć jedna. W pierwszym z tych tytułów znalazła się nawet publikacja $\mathrm{z}$ aż ponad 60 tabelami. W analizowanych czasopismach ogólnohistorycznych nawet proste tabele sa rzadkościa.

Zaprezentowane powyżej różnice w częstości sięgania po metody statystyczne można próbować w jakimś stopniu tłumaczyć epokami historycznymi, w których specjalizują się poszczególne czasopisma. Na wykresie 3 przedstawione zostały za pomoca słupków rozkłady procentowe oddające częstotliwość, z jaką teksty dotyczące poszczególnych epok zawierają choć jeden wykres lub tabelę. Widoczne obok nich linie opisuja z kolei udział procentowy danego okresu historycznego $\mathrm{w}$ puli wszystkich opublikowanych $\mathrm{w}$ danym czasopiśmie artykułów. Znaczenie tej drugiej informacji okazuje się szczególnie istotne w przypadku RH. Widoczna w odniesieniu do nich wyraźna specjalizacja w historii średniowiecza stanowi podstawowa przyczynę niskich wyników tego czasopisma we wszystkich prowadzonych tu analizach. Mediewiści związani ze środowiskiem poznańskim tylko w 4\% przypadków sięgali po omawiane tu metody prezentacji danych ilościowych. Wynik ten jest niski nawet $\mathrm{w}$ porównaniu z historykami średniowiecza publikującymi w PH (około 7\% artykułów zawierało tabele lub wykresy). O tym, że omawianą epokę badać można w sposób znacznie bardziej kwantytatywny świadczą teksty opublikowane w RDSG, gdzie 1/5 spośród nich zawierała choć najprostsze zestawienia statystyczne. Znacznie lepszy wynik PDP został osiagnięty dzięki sporadycznemu podejmowaniu przez polskich demografów historycznych badań nad średniowieczem - spośród zaledwie kilku tekstów na ten temat wszystkie zawierały tabele.

Prezentacja danych w podziale na epoki pozwala stwierdzić, że w przypadku PH, czyli czasopisma dostarczajacego do wykorzystanej tu bazy danych najwięcej rekordów, a także RDSG, graficzna prezentacja wyników najczęściej pojawiała się w pracach dotyczących historii nowożytnej. Wynikowi takiemu trudno się dziwić, skoro przez lata publikowali w nich liczne teksty badacze związani z opisywanymi przez Annę Sosnowską szkołami wybitnych historyków społeczno-gospodarczych, którzy najwięcej uwagi poświęcali właśnie epoce nowożytnej9 Zbiorcza analiza związków między stosowaniem metod statystycznych a okresem historycznym i tytułem czasopisma wskazuje jednak

${ }^{9}$ Dotyczy to zwłaszcza szkół Mariana Małowista, Jerzego Toposkiego i Andrzeja Wyczańskiego, a w mniejszym stopniu także Witolda Kuli - por. A. Sosnowska, Zrozumieć zacofanie. Spory historyków o Europę Wschodniq (1947-1994), Warszawa 2004. 
wyraźnie, że kluczowe znaczenie miał przede wszystkim ostatni z tych czynników. O tym, czy w artykule pojawią się tabele lub wykresy, decydowało przede wszystkim miejsce wydania, a dopiero w drugiej kolejności epoka.

Wykres 3. Występowanie tabel i wykresów w artykułach zamieszczonych w wybranych czasopismach historycznych w latach 1951-2010 z podziałem na epoki

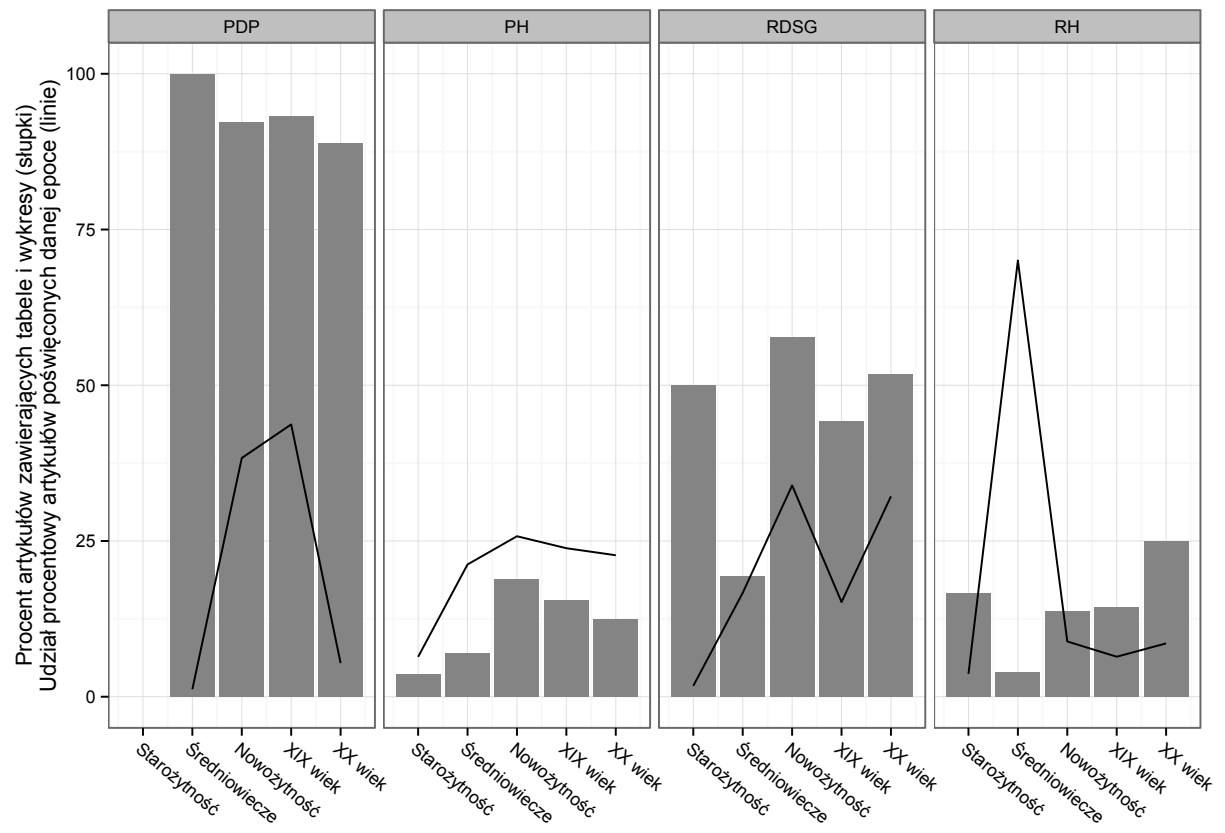

Powyższa obserwacja nie oznacza jednak, że wymiar temporalny nie ma w prowadzonych tu analizach bardzo istotnego znaczenia. Jego rola okazuje się doniosła, ale nie chodzi tu o epokę historyczna, której poświęcony został artykuł, ale raczej o rok jego opublikowania. Jak wynika z wykresu 4, z wyjątkiem PDP omawiane tu czasopisma doświadczyły wyraźnego spadku wykorzystywania metod statystycznych. Prezentujace to zjawisko linie interpretowane być moga w sposób podobny do dobrze historykom znanej średniej ruchomej ${ }^{10} \mathrm{i}$ oddaja średnia liczbę tabel i wykresów przypadajacych na artykuł opublikowany $\mathrm{w}$ danym roku. Widoczną na wykresie zależność uznać należy za paradoksalna - im bardziej upowszechniały się w Polsce komputery, co

${ }^{10} \mathrm{~W}$ praktyce jest to nieco bardziej matematycznie skomplikowana lokalna regresja nieparametryczna (loess) - por. W.S. Cleveland, Robust Locally Weighted Regression and Smoothing Scatterplots, „Journal of the American Statistical Association” 74, 1979, nr 368, s. 829-836. 
powinno pozwalać na szybsze i prostsze korzystanie z metod statystycznych, tym rzadziej po te metody sięgano. Badacze z lat 50., korzystający z kartki i ołówka, okazali się bardziej „kwantytatywni” od swych znacznie lepiej w statystyczne narzędzia wyposażonych następców. Zaś szczególnie silny regres nastapił w latach 80. i 90., czyli w momencie upowszechnienia się komputerów PC, arkuszy kalkulacyjnych, pakietów statystycznych wykorzystujących graficzny interfejs użytkownika. Na marginesie można tu zauważyć, że kryzys ten polegał nie tylko na zwyczajnym spadku liczby tabel i wykresów, uproszczeniu uległy też wykorzystane metody kwantytatywne. O ile w latach 70. polscy historycy sięgali czasem po techniki takie jak regresja, analiza czynnikowa, różnorakie metody klasyfikacyjne, to później podejścia takie porzucono.

W ostatniej dekadzie jedynie PDP wyraźnie odbiło się od dna obserwowanego w latach 90 . Niewielki, ale jednak dostrzegalny wzrost udziału tabel i wykresów publikowanych na łamach RDSG daje nadzieję, że i w przypadku tego czasopisma powoli dochodzić będzie do poprawy. Z kolei dwa analizowane tu czasopisma ogólnohistoryczne kontynuowały w ciagu ostatnich lat wcześniejszy trend spadkowy i sa już właściwie całkowicie pozbawione jakichkolwiek form graficznej prezentacji danych kwantytatywnych.

Wykres 4. Lokalna regresja wielomianowa opisująca liczbę tabel lub wykresów w artykułach zamieszczonych w wybranych czasopismach historycznych w latach 1951-2010

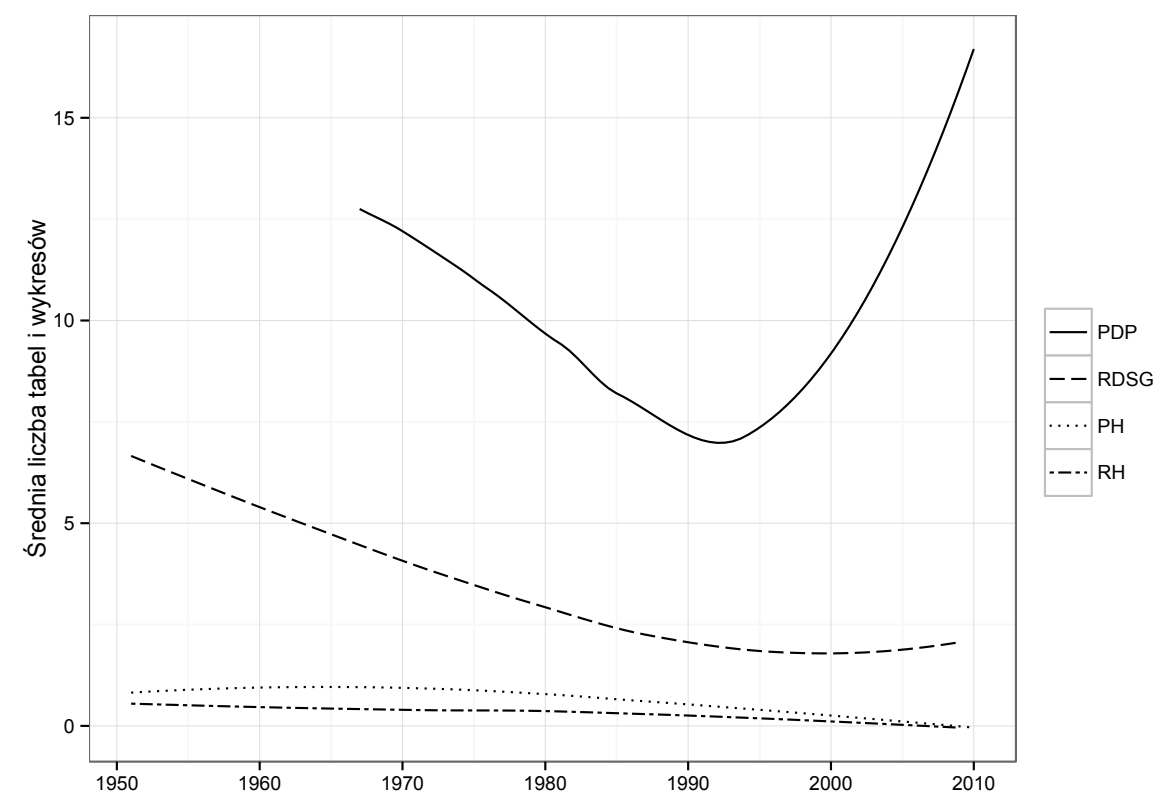


Omawiane tu zjawisko odwrotu od wykorzystania metod statystycznych, które obserwować można w przypadku większości analizowanych czasopism, ma konsekwencje sięgające poza kwestie naukowej mody. Gdyby chodziło tylko o nia, skargi na spadek znaczenia metod statystycznych mogłyby sprowadzać się jedynie do krytyki opartej na preferencjach osób piszacych te słowa i zostać łatwo odrzucone w myśl zasady, iż o upodobaniach się nie dyskutuje. Niestety, obserwowane w polskiej historiografii zjawisko odwrotu od metod kwantytatywnych ma konsekwencje wykraczające poza zagadnienie osobistych wyborów poszczególnych badaczy. Prowadzi ono do pogłębiania się dystansu między rodzimą a światową historiografią społeczno-gospodarczą. Polski badacz, wychowany na krajowej literaturze i przyzwyczajony do metod w niej stosowanych, okazać się może całkowicie nieprzygotowany do lektury prac obcych, szeroko wykorzystujacych techniki statystyczne. Choćby pobieżny przegląd zawartości tak kluczowych międzynarodowych czasopism z zakresu historii społeczno-gospodarczej jak „The Economic History Review”, „Histoire \& Mesure”, „Histoire, économie \& société”, nie wspominając już o „European Review of Economic History”, „The Journal of Economic History” czy „Explorations in Economic History" ukazuje wyraźnie, jak ogromna przepaść dzieli w tym względzie historiografię polską od światowej. Metody tam powszechnie wykorzystywane, jak choćby: różnorodne techniki regresji, analiza korespondencji i czynnikowa oraz algorytmy klasyfikacyjne, okazuja się dla większości polskich historyków całkowicie niezrozumiałe. Dane podobne do zaprezentowanego $\mathrm{w}$ tabeli modelu regresji logistycznej, przewidującego stosowanie $\mathrm{w}$ polskich publikacjach technik ilościowych ${ }^{11}$, odnaleźć można niemal w każdym numerze wspomnianych powyżej czasopism zagranicznych, gdy tymczasem w rodzimych sa właściwie niespotykane. Skoro polscy historycy z metod tych nie korzystaja, a często też ich nie rozumieja, praktycznie niemożliwa staje się międzynarodowa współpraca, porównywanie otrzymanych wyników, włączanie rezultatów naszych badań do powstających na Zachodzie

\footnotetext{
${ }^{11}$ Model ten przewiduje, z jakim prawdopodobieństwem w artykułach występować będą tabele oraz wykresy. Analiza współczynników widocznych w kolumnie zatytułowanej $\operatorname{Exp(B)}$ wskazuje na największe prawdopodobieństwo występowania tabel i wykresów w PDP (wzrasta ono w porównaniu z RH 122 razy) a następnie RDSG (w porównaniu z RH prawdopodobieństwo jest dziewięciokrotnie większe) i PH (dwukrotny wzrost szansy na wystapienie tabel i wykresów w porównaniu z $\mathrm{RH}$ ). Wyraźnie większe szanse na występowanie tabel i wykresów rysują się również w odniesieniu do artykułów opublikowanych w latach 1961-1970 oraz poświęconych epoce nowożytnej. Prawdopodobieństwo wzrasta też wraz z objętością artykułu.
} 
syntez. W takiej sytuacji trudno się dziwić, że w wielu zagranicznych pracach ziemie polskie przedstawiane sa jako obszar zacofany cywilizacyjnie i niezbyt interesujący. Wystarczy wskazać tu na ważne publikacje Jana Luitena van Zandena, zawierajace informacje o wydaniu przez polskie drukarnie w XVI w. tylko około 200 tytułów książek lub nieistnieniu w nowożytnej Polsce „prawdziwego” parlamentu ${ }^{12}$. Choć rodzimi badacze słusznie moga się na takie twierdzenia oburzać, to dopóki nie podejma z nimi polemiki przy pomocy nowoczesnych i powszechnie przyjętych metod kwantytatywnych, dopóty ich głos nie będzie na Zachodzie słyszany ${ }^{13}$.

Tabela 1. Model regresji logistycznej wyjaśniajacy występowanie tabel i wykresów $\mathrm{w}$ artykułach zamieszczonych w wybranych czasopismach historycznych w latach 1951-2010

\begin{tabular}{|c|c|c|c|c|}
\hline & & $\mathbf{B}$ & $\operatorname{Exp}(B)$ & Istotność \\
\hline \multirow{3}{*}{$\begin{array}{l}\text { Czasopismo } \\
\text { (RH jako punkt odniesienia) }\end{array}$} & PDP & 4,80 & 122,03 & 0,00 \\
\hline & $\mathrm{PH}$ & 0,75 & 2,12 & 0,01 \\
\hline & RDSG & 2,22 & 9,22 & 0,00 \\
\hline \multirow{5}{*}{ Epoka } & Starożytność & 0,91 & 2,48 & 0,16 \\
\hline & Średniowiecze & 0,91 & 2,48 & 0,11 \\
\hline & Nowożytność & 2,17 & 8,75 & 0,00 \\
\hline & XIX w. & 1,83 & 6,21 & 0,00 \\
\hline & XX w. & 1,89 & 6,63 & 0,00 \\
\hline \multicolumn{2}{|l|}{ Liczba stron } & 0,04 & 1,04 & 0,00 \\
\hline \multirow{5}{*}{$\begin{array}{l}\text { Dekada } \\
\text { (2001-2010 jako punkt } \\
\text { odniesienia) }\end{array}$} & 1951-1960 & 0,67 & 1,95 & 0,01 \\
\hline & $1961-1970$ & 1,14 & 3,11 & 0,00 \\
\hline & $1971-1980$ & 1,05 & 2,86 & 0,00 \\
\hline & $1981-1990$ & 0,92 & 2,50 & 0,00 \\
\hline & $1991-2000$ & 0,24 & 1,27 & 0,34 \\
\hline \multicolumn{2}{|l|}{ Stała } & $-5,90$ & 0,00 & 0,00 \\
\hline \multicolumn{2}{|l|}{ R kwadrat Nagelkerkego } & 0,39 & & 0,00 \\
\hline \multicolumn{2}{|l|}{ Liczba obserwacji } & 2602 & & \\
\hline
\end{tabular}

${ }^{12}$ J.L. van Zanden, E. Buringh, M. Bosker, The Rise and Decline of European Parliaments 1188-1789, „The Economic History Review” 65, 2012, z. 3, s. 835-861. Szczegółowe wyjaśnienie zastosowanej w tekście metodologii znajduje się w załaczniku umieszczonym na stronie internetowej czasopisma - http://onlinelibrary.wiley.com/ doi/10.1111/j. 1468-0289.2011.00612.x/suppinfo.

${ }^{13}$ Osobna sprawa jest problem słyszalności głosu polskich badaczy dziejów gospodarczych i demografii dawnych społeczeństw w środowisku historyków, dla których statystyczne ujęcie tematu jest rzadkością. W tym wypadku wyrafinowane metody kwantytatywne raczej nie wpłyną pozytywnie na adaptację wyników do głównych nurtów historiografii. 
Oczywiście autorzy niniejszego tekstu zdają sobie sprawę, że ilościowa analiza źródeł jest jedna z wielu metod historycznych i nie nadaje się do wszystkich tematów badawczych. Oferuje jednak ona niezaprzeczalna szansę rozwijania historiografii porównawczej, pozwala najlepiej badać zjawiska masowe, ułatwia jasne formułowanie hipotez badawczych, a następnie ich weryfikowanie w trakcie analizy, przede wszystkim zaś uczy odpowiedzialności za słowa w pracach naukowych. W powszechnym użyciu przez historyków z dystansem traktujących na co dzień metody statystyczne są wyrażenia kwantyfikujące, takie jak: większość, dużo, zazwyczaj, rzadko itp., za którymi kryje się intuicja autora, a nie rzetelna analiza zjawiska. Metody kwantytatywne wymagaja konkretów i precyzji, a także wytrwałości w konstruowaniu baz danych. Często efekty wielomiesięcznej pracy są zaprezentowane w precyzyjnie zrobionych tabelach i wykresach, których znaczenie wprawiony badacz ilościowy potrafi ocenić i bez wgłębienia się w opis. Należy jednak pamiętać, że dla historyka niestosującego metod statystycznych opis jest ważniejszy od najlepiej skonstruowanej graficznej prezentacji wyników i nie da się upowszechniać w środowisku wyników badań demograficznych i gospodarczych bez dobrze skomponowanej narracji.

Zresztą sytuacja tych dwóch nurtów badań w ostatnich latach nie jest jednakowa. Historia gospodarcza przeżywa widoczny kryzys, będacy $\mathrm{w}$ pewnym sensie wynikiem reakcji środowiska historycznego na instytucjonalne jej faworyzowanie we wczesnej PRL. Konsekwencje tego swoistego buntu sa długofalowe. Twórcy nowych podręczników akademickich praktycznie nie zastosowali wykresów i tabel w swoich ujęciach dziejów Polski, choć zazwyczaj w jakimś stopniu doceniali znaczenie badań nad historia gospodarczą. Widoczny brak ciagłości badań, zwłaszcza po śmierci wybitnych historyków gospodarczych, takich jak Benedykt Zientara, Antoni Mączak, Jerzy Topolski, Andrzej Jezierski czy Andrzej Wyczański, sprawił, że załamaniu uległy ramy instytucjonalne współpracy środowiska. Od wielu lat nie działa komisja historii gospodarczej PAN, obecność polskich historyków na światowych kongresach gospodarczych jest mniejsza niż w okresie komunistycznym, a młode pokolenia adeptów historii preferuja tradycyjna historiografię polityczna i wojskowa, modne badania nad dziejami kultury, mentalnością czy antropologię historyczną.

Nieco inaczej wygląda sytuacja demografii historycznej, która z początkującej na gruncie polskim dyscypliny rozwinęła się w prężny nurt historiografii, reprezentowany na wspomnianym międzynarodowym kongresie historycznym w Amsterdamie najliczniej spośród 
całego środowiska polskich historyków. Niestety wszystko to odbywa się $\mathrm{w}$ pewnej izolacji, wynikającej zarówno ze specyfiki badań kwantytatywnych, jak i małej świadomości znaczenia problemów demograficznych w dziejach ludzkości. Wydaje się, że w interesie zarówno historyków gospodarczych, jaki i demografów historycznych jest wyjście poza własne środowisko i publikowanie nie tylko w czasopismach branżowych, takich jak RDSG czy PDP, z zastosowaniem nowoczesnych i zaawansowanych metod statystycznych, ale również prezentacja wyników na łamach czasopism ogólnohistorycznych, być może przy użyciu mniej hermetycznego języka i uproszczonego aparatu statystycznego. Nie spełniły się przewidywania Emmanuela Le Roy Ladurie, że historyk albo będzie programista, albo nikim. Rację miał jednak Andrzej Wyczański piszacy: „Liczba w badaniach historycznych odgrywała, odgrywa i będzie odgrywała coraz większą rolę, jednakże ujęcia kwantytatywne nie moga być jedyną drogą badawcza, lecz winny stanowić mniej lub bardziej ważne narzędzie wśród różnych umiejętności badawczych historyka, natomiast brak umiejętności posługiwania się liczbą nie dyskwalifikuje go wprawdzie, ale jest brakiem jednej z istotnych umiejętności badawczych. W żadnym wypadku nie można jej uznawać za zaletę historyka jako humanisty"14.

Historia gospodarcza i demografia historyczna opierają się na liczbie, a liczba w źródle to taki sam element podlegający analizie i krytyce, jak każdy inny tekst. Świadomości tych prostych faktów brakuje wśród przedstawicieli głównych współczesnych nurtów polskiej historiografii. Z drugiej strony historycy gospodarczy i demografowie historyczni powinni oczywiście pamiętać, że rolą historyka jest opowiadanie historii, a nie rysowanie tabel i wykresów.

Piotr Guzowski

Radosław Poniat

The place of quantitative research in modern Polish historiography (Summary)

The article discusses the use of quantitative methods in studies on Polish history. The database with information on tables and schedules in annual volumes of selected specialist (general and socio-economic history) journals

${ }^{14}$ Tenże, Historyk wobec liczby, w: Metody i wyniki. Z warsztatu historyka dziejów społeczeństwa polskiego, red. S. Kalabiński, współudział J. Hensel, I. Rychlikowa, Warszawa 1980, s. 31. 
and other periodicals was the basis for the deliberations. A statistical analysis of the data obtained showed a gradual decline in the use of quantitative methods. From the 1970s, tables and graphs took up less and less space in the periodicals and statistical techniques were gradually simplified. With the exception of "Przeszłość Demograficzna Polski" (Poland's Demographic Past) this process continues. In the authors' opinion this increases the gap between Polish and global socio-economic historiography.

Key words: quantitative methods, socio-economic history 